\title{
Geochemical Characterization and Economic Potential of Emure and ljero Ekiti Pegmatites in Southwest Nigeria
}

\author{
M. Ilevbare*, A. Orisamika \\ Department of Geology, Physical Sciences, University of Benin, Benin City, Edo State, NIGERIA.
}

\begin{abstract}
Global demand increase for rare metals deposits has re-enacted the search for economically viable deposits. Precambrian pegmatites occurring as near dykes and massive types were studied for Emure-Ekiti and Ijero-Ekiti respectively, with the aim of characterizing them geochemically and determining their possible economics values. A total of twelve samples comprising seven from Emure-Ekiti, three whole rock muscovite extract for Ijero-Ekiti were analysed for major and trace elements using X-ray fluorescence method. Thin sections prepared for the Emure-Ekiti pegmatites show that quartz, microcline are major mineral constituents. The geochemical results reveals that the Emure-Ekiti and the whole rock samples of Ijero-Ekiti are considerably siliceous, with an average value of $68.72 \%$ and $68.6 \%$ respectively, while the muscovites extracts average $48.86 \%$. Mean values of major oxides for the Emure, Ijero[whole rock, muscovite] are as follows; $\mathrm{Al}_{2} \mathrm{O}_{3}-20.42 \%$, [13.74\%, 35.15\%]; $\mathrm{Fe}_{2} \mathrm{O}_{3}-1.83 \%$, [1.24\%, 2.19\%]; $\mathrm{MgO}$ - 0.013\%, [0.029\%, 1.04\%]; $\mathrm{CaO}-0.02 \%,[0.34 \%, 2.4 \%] ; \mathrm{Na}_{2} \mathrm{O}-1.01 \%,[4.40 \%, 1.045 \%] ; \mathrm{K}_{2} \mathrm{O}-3.17 \%,[2.77 \%$, 11.07\%]. Trace and rare-earth elements result shows that the Emure-Ekiti pegmatites is "barren" - depleted in rare metals Ta, Nb, Cs, Sn, Rb, etc, and compare favourably with Apomu, Ago-Iwoye and Ijebu-Ife barren pegmatites. On the other hand, two of the whole rock samples are mineralized-fairly enriched in rare metals $T a, N b, R b$ while the remaining sample and the muscovite extract are barren; as depicted by the $R b$ vs $R b$ plot and when compared to the other rare metal pegmatites across the world.
\end{abstract}

Keywords: Emure-Ekiti, Ijero-Ekiti, pegmatites, characterization, geochemical, economic value

\section{INTRODUCTION}

Pegmatites are very coarse-grain igneous or metamorphic rocks, generally of granitic compositions. They are texturally distinct variants of more common and more voluminous plutonic igneous rocks, including gabbrous, syenites e.t.c. Pegmatites bodies vary greatly in size and shape i.e. they occur as segregations within granites and as sharp discordant dikes intruding igneous and metamorphic rocks. Other fabrics include systematic coarsening in crystal size from the margins to the centres of bodies; sharp mineralogical zonations from margin to centre; anisotropic fabrics and graphics intergrowth of quartz and feldspar termed "graphic granite" [1].

Pegmatites fields are widespread in south western Nigeria. The early workers [2, 3], on the pegmatites of south western Nigeria, while working on the Osu and Aramoko pegmatites recognized that the pegmatites of Osu area is emplaced into schistose and gneissic basement units which comprises microcline, sodic feldspar and quartz minerals with an average rock $\mathrm{Na} / \mathrm{K}=0.77$, while

${ }^{*}$ Corresponding author (Tel: +234 (0)803 699 3220)

Email addresses: ilevbaremartins777@gmail.com (M. Ilevbare), talk2debor@yahoo.com (A. Orisamika) pegmatites of Aramoko area is closely associated with the granodioritic main phase older granite, steeply tabular pegmatites which are composed mainly of microcline and quartz with an average rock $\mathrm{Na} / \mathrm{K}=0.16$. In a related study work on pegmatites source rocks related to the PanAfrican Orogeny within and around Ijero-Ekiti found out that the degree of specialization of massive Ijero-Ekiti pegmatites are marked by albitization. Also, their work revealed that the $\mathrm{Rb}$ and Li concentrations are all within the range of barren pegmatites and other granitoids [4]. In another study [5, 6], studied the geochemical exploration for Sn-Nb-Ta in South western Nigerian, while [3] studied the pegmatites of Pan-African reactivation zones covering areas of Egbe-Ijero and Wamba ,and also distinguished mainly between the barren and mineralized pegmatites. In a related study, [7] documented the metallogeny of the Nigeria basement complex rocks including the pegmatites. Similarly, [8] worked on the geochemical exploration guides of rare metal bearing pegmatites with case studies of Ijero and Wamba.

The contributions of [9-15] have also contributed to the better understanding of south western and northern Nigeria pegmatites bodies and concluded that the pegmatites were not confirmed to earlier proposed $400 \mathrm{~km}$ long NE-SW 


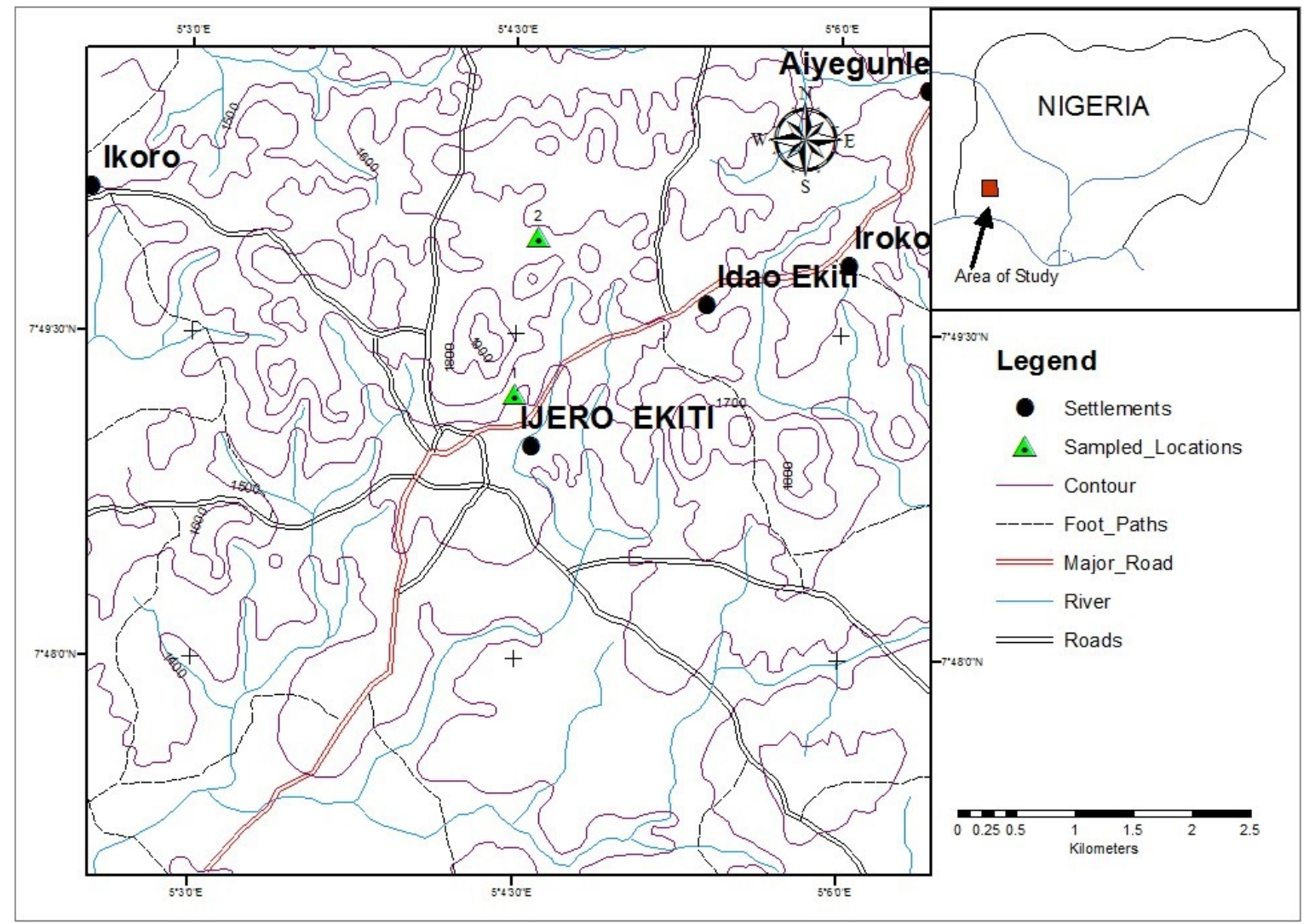

Figure 1: Location map of Ijero-Ekiti and Environs.

rending belt. Furthermore, [16, 17] worked on the pegmatites of Komu in Northern part of Oyo State and reported that these pegmatite which intrude semi discordantly older rock types, such as biotite gneiss, amphibolites, microcline, muscovite with accessories like Tourmaline, Tantalum, Niobium and Illmeno-Rutiles with the trace element analysis shows that the pegmatites contain rare metals with moderately high $\mathrm{Ta}, \mathrm{Nb}$, $\mathrm{Sn}, \mathrm{Rb}, \mathrm{Li}$ and $\mathrm{Cs}$ values and depleted in $\mathrm{Ti}, \mathrm{Ba}$ and $\mathrm{Zr}$. The $\mathrm{Na} / \mathrm{K}$ versus $\mathrm{Sn}, \mathrm{Nb}, \mathrm{Rb}$ variation plots shows that the pegmatites of komu area are mineralized and compared favourably with those of other mineralized pegmatite area like Egbe and Ijero in south western Nigeria. Also, the variation plots of Ta versus $\mathrm{K} / \mathrm{Cs}$, and Ta/W versus $\mathrm{Cs}$, also confirmed rare metal mineralization of komu pegmatites, which plot over the mineralized line of Beus and Gordiyenko with the plot of $\mathrm{K} / \mathrm{Rb}$ versus $\mathrm{Rb}, \mathrm{Cs}$ and $\mathrm{Sn}$ plots indicate low $\mathrm{K} / \mathrm{Rb}$ ratios indicating moderate differentiation. Recently, [18] studied the geochemical features of the Precambrian Pan-African pegmatites of IjebuIfe area in south western Nigeria and concluded that the Ijebu-Ife pegmatites are fairly enriched in $\mathrm{Rb}, \mathrm{Sr}, \mathrm{Zr}$ but comparatively poor in the rare metals $\mathrm{Ta}, \mathrm{Nb}, \mathrm{Cs}$ and $\mathrm{Sn}$. Rare metal mineralization enrichment indices mainly, $\mathrm{Ta} \mathrm{Vs} \mathrm{Nb}$, Ta Vs K/Cs plots, shows it depletion in rare metal mineralization, suggestingthis pegmatites To be barren in rare-metal mineralization when compared with other rare metal pegmatites cross the world. In the same vein, [19] studied the geochemical and compositional features of Precambrian pegmatites of Ago- Iwoye area- South western Nigeria and reported that though the samples are fairly enriched in $\mathrm{Rb}, \mathrm{Sr}, \mathrm{Zr}$ but are comparatively poor in the rare metals $\mathrm{Ta}, \mathrm{Nb}, \mathrm{W}, \mathrm{Cs}$ and $\mathrm{Sn}$; with the rare metal mineralization enrichment indices show its depletion in rare metal mineralization suggesting Ago-Iwoye Pegmatites to be barren in rare metal mineralization when compared with other rare metal pegmatites across the world. This study seeks to carry out a comprehensive geochemical study of the Pegmatite bodies in Emure Ekiti area and also to determine the mineralogy of the pegmatites using both visual and instrumental observations and to compare the mineralogy and geochemistry of the pegmatites and with those of the other parts of Nigeria and the world.

\section{LOCATION AND ACCESSIBILITY}

Ijero-Ekiti (Fig. 1) the second area of study lies between latitudes $70^{\circ} 47^{\prime \prime} \mathrm{N}$ and $70^{\circ} 51^{\prime \prime} \mathrm{N}$ and longtitudes $50^{\circ} 02^{\prime \prime} \mathrm{E}$ and $50^{\circ} 05^{\prime \prime} \mathrm{E}$ on sheet 244 of the Federal Survey Sheet. It has a total area cover of about $170 \mathrm{Km}$. other towns around the area include Ikoro-Ekiti, Ara, Idao, Epe, Ayegunle, Ijurin, Ipoti and Iloro. While on the other hand; Emure Ekiti (Fig. 2) is a town located in the eastern part of Ekiti state. It is situated about $50 \mathrm{~km}$ southwest of Ikere-Ekiti and it is one of the towns that constitute Emure local government area of 


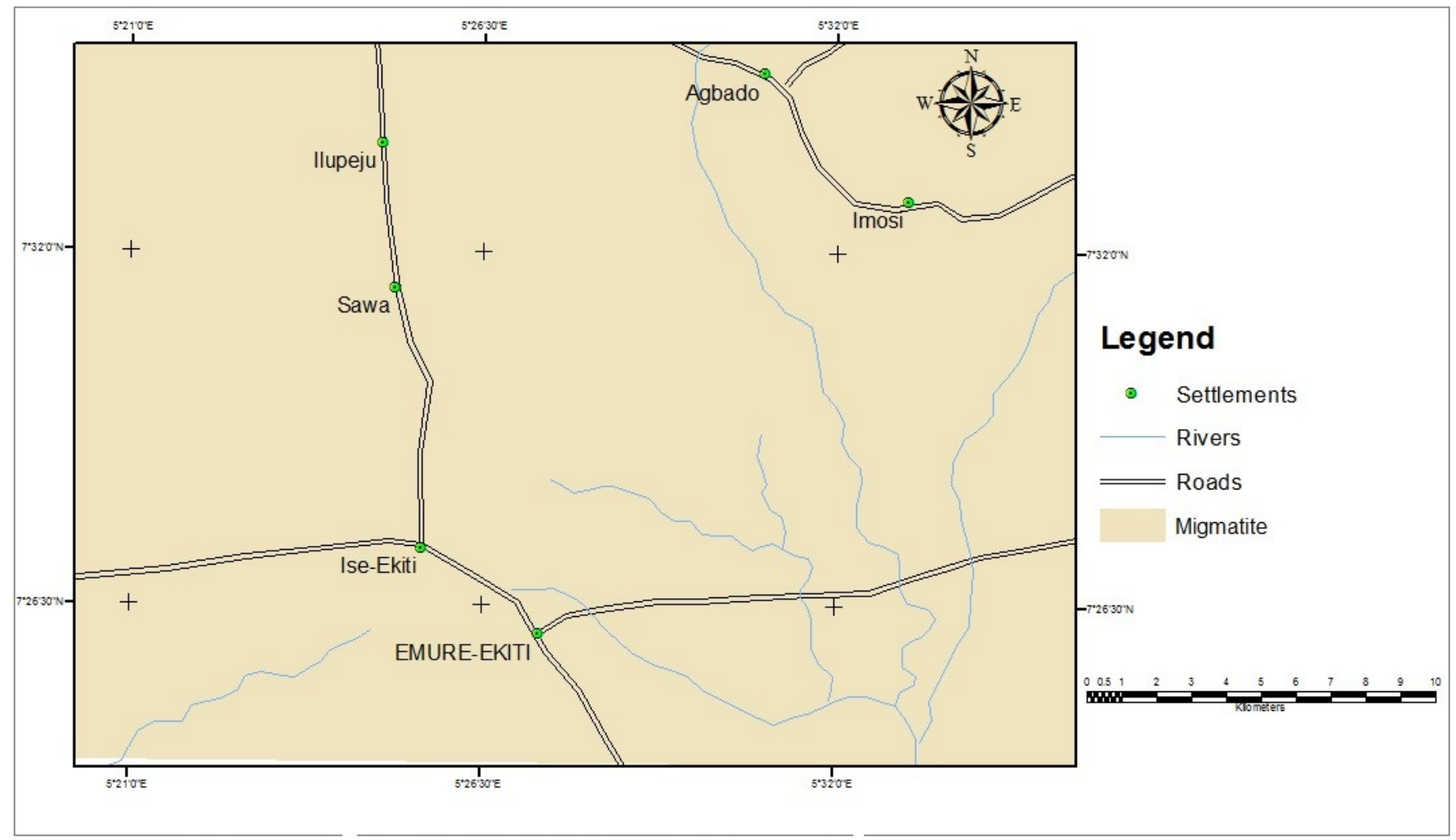

Figure 2: Location map of Emure-Ekiti and Evirons.

Ekiti State. The study area is a part of the town that is situated between latitudes $70^{\circ} 25^{\prime} 10^{\prime \prime}$ and $70^{\circ} 25^{\prime} 30^{\prime \prime}$ and longitudes $50^{\circ} 26^{\prime} 35^{\prime \prime}$ and $50^{\circ} 25^{\prime} 40^{\prime \prime}$ and is easily accessible through the major, minor roads and footpaths.

\section{METHODS}

This research involved detailed mapping and sampling of the pegmatite bodies with accurate locations of each sampled points made by using the GPS. Single bead low-dilution fusion technique was adopted for the XRF analysis. The fresh chips of the sample are hand-picked and a standard volume of chips (approximately $28 \mathrm{~g}$ ) is ground in a swing mill with tungsten carbide surfaces for 2 minutes. Three and a half grams (3.5 g) of the sample powder is weighed into a plastic mixing jar with $7.0 \mathrm{~g}$ of spec pure dilithium tetraborate $\left(\mathrm{Li}_{2} \mathrm{~B}_{4} \mathrm{O}_{7}\right)$ and assisted by an enclosed plastic ball, mixed for ten minutes. The mixed powders are emptied into graphite crucibles with internal measurements of $34.9 \mathrm{~mm}$ diameter by 31.8 mm deep. Twenty four (24) filled crucibles are placed on a silica tray and loaded into a muffle furnace only large enough to contain the tray. Fusion takes 5 minutes from the time the preheated furnace returns to its normal $1000^{\circ} \mathrm{Cafter}$ loading. The silica plate and graphite crucibles are then removed from the oven and allowed to cool. Each bead is reground in the swing mill for 35 seconds, the glass powder then replaced in the graphite crucibles and refused for 5 minutes.
Following the second fusion, the cooled beads are labeled with an engraver, their lower flat surface is ground on 600 silicon carbide grit, finished briefly on a glass plate (600 grit with alcohol) to remove any metal from the grinding wheel, washed in an ultrasonic cleaner, rinsed in alcohol and wiped dry. The glass beads are then ready to be loaded into the XRF spectrometer. Preparation of a single bead takes, on average, 45 minutes.

\section{RESULTS}

This sub-section focuses on the sequential presentation of the geochemical analysis of the pegmititte in the study area for both major metallic oxides in percentages and the trace and rare earth metals in ppm see in Tables 1 and 2 and also a comparison of the geochemistry of the pegmatites in Emure and Ijero-Ekiti samples with selected pegmatites samples from other parts of Nigeria and the world presented in Table 3.

The weight percentage result of the samples, show that the Emure pegmatite is highly siliceous and aluminous with $65.80 \%-72.76 \%$ for $\mathrm{SiO}_{2}$ and $18.99 \%-22.32 \%$ for $\mathrm{Al}_{2} \mathrm{O}_{3}$ wt $\%$. The data also show that potash, $\mathrm{K}_{2} \mathrm{O}$ ranges between $2.90-$ $3.40 \mathrm{wt} \%$, while Soda, $\mathrm{Na}_{2} \mathrm{O}$ and quicklime, $\mathrm{CaO}$ ranges between $0.75-1.30 \mathrm{wt} \%$ and $0.02-0.04$ wt \% respectively. The high ratio of $\mathrm{Al}_{2} \mathrm{O}_{3} / \mathrm{Na}_{2} \mathrm{O}$ $+\mathrm{K}_{2} \mathrm{O}+\mathrm{CaO}$ is the various samples imply that the pegmatite is peraluminous while the high ratio of $\mathrm{K}_{2} \mathrm{O} / \mathrm{Na}_{2} \mathrm{O}+\mathrm{CaO}$ implies a pegmatite rich in orthoclase a potassium feldspar. 
Table 1: Major and Trace elements Composition of Emure-Ekiti Pegmatites.

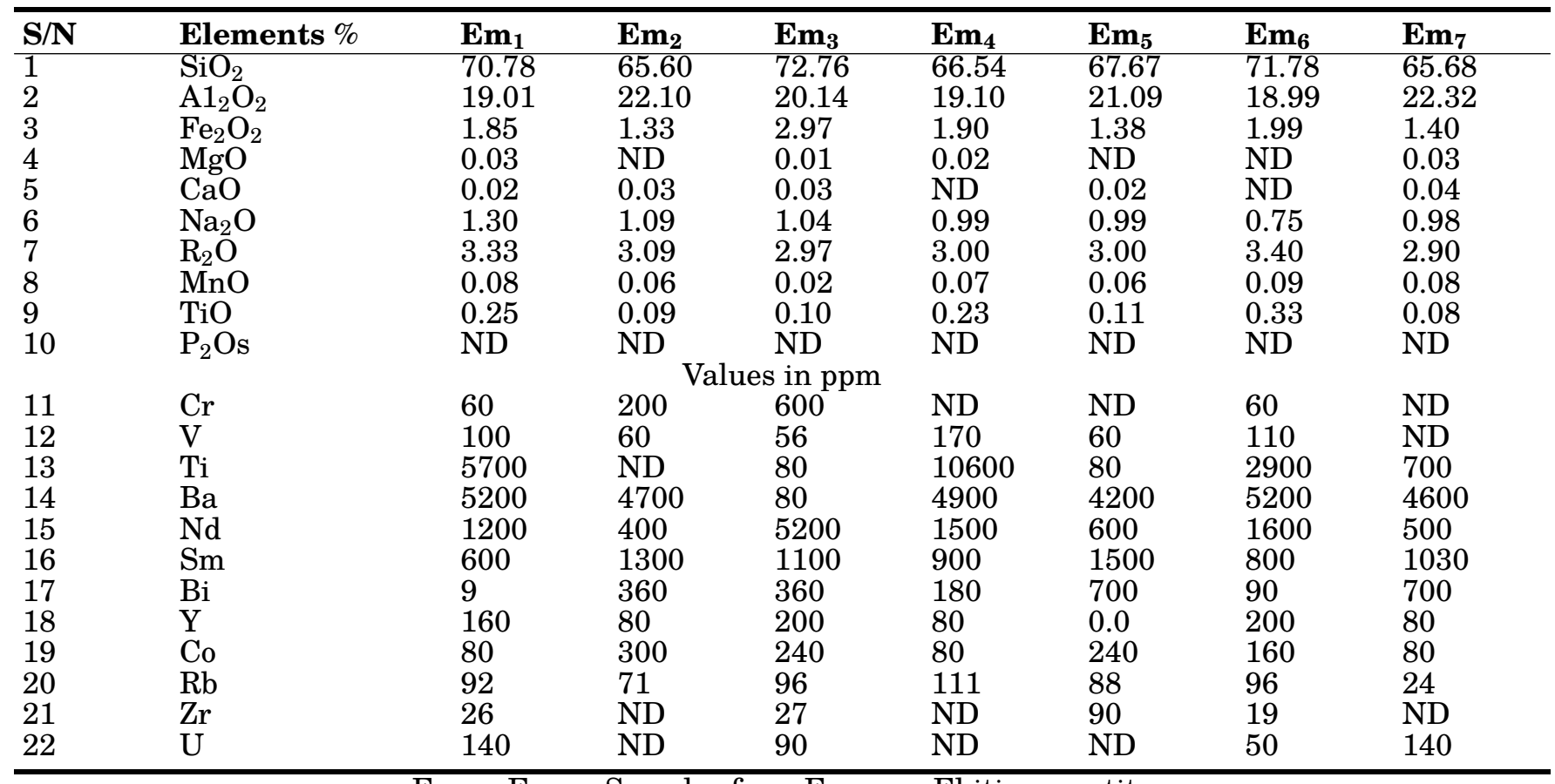

$\mathrm{Em}_{2}-\mathrm{Em}_{2}=$ Samples from Emure - Ekiti pegmatite

Table 2: Major and trace elements composition of Ijero-Ekiti Pegmatites.

\begin{tabular}{|c|c|c|c|c|c|c|}
\hline \multirow[t]{2}{*}{$\overline{\mathbf{S} / \mathbf{N}}$} & \multirow{2}{*}{ Elements \% } & \multicolumn{3}{|c|}{ Whole Rock } & \multicolumn{2}{|c|}{ Muscovite } \\
\hline & & $J_{1}$ & & $J_{3}$ & $\mathrm{~J}_{4}$ & $J_{5}$ \\
\hline 1 & $\mathrm{SiO}_{2}$ & 71.00 & 68.20 & 66.6 & 44.05 & 43.66 \\
\hline 2 & $\mathrm{~A} 1_{2} \mathrm{O}_{2}$ & 14.40 & 14.22 & 12.60 & 35.92 & 34.37 \\
\hline 3 & $\mathrm{Fe}_{2} \mathrm{O}_{2}$ & 0.91 & 1.12 & 1.7 & 1.72 & 2.66 \\
\hline 4 & $\mathrm{MgO}$ & 0.20 & 0.19 & 0.46 & 0.90 & 1.18 \\
\hline 5 & $\mathrm{CaO}$ & 0.46 & 0.44 & 0.12 & 1.89 & 2.86 \\
\hline 6 & $\mathrm{Na}_{2} \mathrm{O}$ & 4.28 & 6.45 & 2.45 & 1.87 & 1.22 \\
\hline 7 & $\mathrm{~K}_{2} \mathrm{O}$ & 1.82 & 1.69 & 4.80 & 8.72 & 8.99 \\
\hline 8 & $\mathrm{MnO}$ & 0.08 & 0.09 & 0.07 & 0.07 & 0.05 \\
\hline 9 & $\mathrm{TiO}$ & 0.05 & 0.18 & 0.05 & 0.08 & 0.07 \\
\hline 10 & $\mathrm{P}_{2} \mathrm{Os}$ & 0.04 & 0.03 & 0.01 & 0.07 & 0.02 \\
\hline & & & Values in ppm & & & \\
\hline 11 & $\mathrm{~V}$ & 100 & 60 & ND & 60 & 60 \\
\hline 12 & $\mathrm{Cr}$ & ND & 70 & ND & ND & 70 \\
\hline 13 & $\mathrm{Ba}$ & 80 & 40 & 30 & 90 & 90 \\
\hline 14 & $\mathrm{Ta}$ & 77 & 74 & 60 & 40 & 40 \\
\hline 15 & $\mathrm{Nb}$ & 108 & 79 & 74 & 47 & 67 \\
\hline 16 & Sn & 28 & 21 & 52 & 61 & 70 \\
\hline 17 & $\mathrm{Rb}$ & 345 & 640 & 460 & 180 & 300 \\
\hline 18 & $\mathrm{Y}$ & 80 & ND & 80 & 160 & 80 \\
\hline 19 & $\mathrm{U}$ & 46 & 47 & 60 & 110 & 102 \\
\hline 20 & $\mathrm{Zr}$ & 47 & 45 & 57 & 60 & 60 \\
\hline 21 & $\mathrm{Sr}$ & 40 & 47 & 46 & 45 & 45 \\
\hline
\end{tabular}


Table 3: Comparison of chemcial composition of Emure and Ijero-Ekiti pegmatites with some selected pegmatites from other parts of Nigeria and the World.

\begin{tabular}{|c|c|c|c|c|c|c|c|c|}
\hline $\mathbf{S} / \mathbf{N}$ & Elements \% & $\mathbf{A}$ & B & $\mathbf{C}$ & $\mathbf{D}$ & $\mathbf{E}$ & $\mathbf{F}$ & $\mathbf{G}$ \\
\hline 1 & $\mathrm{SiO}_{2}$ & 65.90 & 69.31 & 73.74 & 60.35 & 46.65 & 68.72 & 68.60 \\
\hline 2 & $\mathrm{~A} 1_{2} \mathrm{O}_{3}$ & 7.71 & 14.34 & 14.68 & 19.80 & 36.83 & 20.42 & 13.7 \\
\hline 3 & $\mathrm{Fe}_{2} \mathrm{O}_{3}$ & 19.28 & 2.61 & 1.49 & 3.43 & 1.34 & 1.83 & 1.27 \\
\hline 4 & $\mathrm{MgO}$ & 0.049 & 0.78 & 0.18 & 0.26 & 0.21 & 0.013 & 0.28 \\
\hline 5 & $\mathrm{CaO}$ & 0.3 & 1.63 & 0.78 & 0.02 & 0.05 & 0.02 & 0.9 \\
\hline 6 & $\mathrm{Na}_{2} \mathrm{O}$ & 1.89 & 3.31 & 4.46 & 0.70 & 0.82 & 1.83 & 1.27 \\
\hline 7 & $\mathrm{~K}_{2} \mathrm{O}$ & 1.86 & 4.80 & 3.52 & 10.33 & 9.49 & 3.17 & 3.39 \\
\hline 8 & $\mathrm{TiO}_{2}$ & 2.77 & 0.18 & 0.08 & 0.2 & 0.2 & 0.17 & 0.09 \\
\hline 9 & $\mathrm{MnO}$ & 0.056 & 0.05 & 0.4 & 0.16 & & 0.06 & \\
\hline 10 & $\mathrm{P}_{2} \mathrm{O}_{5}$ & 0.12 & 0.08 & 0.202 & 0.11 & & & \\
\hline \multicolumn{9}{|c|}{ Values in $\mathrm{ppm}$} \\
\hline 11 & $\mathrm{Be}$ & 16.9 & 2.73 & 4.5 & 21.00 & 21.00 & & \\
\hline 12 & Co & 1.69 & & & 1.00 & 1.00 & & \\
\hline 13 & $\mathrm{Cs}$ & 9.01 & 5.07 & 4.57 & 195.00 & 195.00 & & \\
\hline 14 & $\mathrm{Ga}$ & 16.20 & 19.01 & 19.01 & 283.00 & 283.00 & & \\
\hline 15 & Hf & 13.00 & 2.25 & 3.82 & & & & \\
\hline 16 & $\mathrm{Nb}$ & 50.60 & 9.46 & 21.88 & 381.00 & 358.00 & & 87.00 \\
\hline 17 & $\mathrm{Rb}$ & 183.99 & 212.96 & 106.85 & 1000.00 & 1479.00 & 83.00 & 482.00 \\
\hline 18 & $\mathrm{Sn}$ & 15.50 & & 3.90 & 78.00 & 2.31 & & 34 \\
\hline 19 & $\mathrm{Sr}$ & 63.18 & 198.15 & 89.43 & 7.00 & 21.00 & 26.00 & 44.00 \\
\hline 20 & $\mathrm{Ta}$ & 8.64 & 1.35 & 6.54 & 76.20 & & & 70.00 \\
\hline 21 & Th & 5.26 & 9.50 & 2.98 & 0.20 & & & \\
\hline 22 & W & 1.15 & & 1.56 & 14.00 & 102.00 & & \\
\hline 23 & $\mathrm{Zr}$ & 440.39 & 68.61 & 102.66 & 3.00 & 10.00 & 23.00 & 50.00 \\
\hline 24 & $\mathrm{~K} / \mathrm{Rb}$ & 183.92 & 187.11 & 273.48 & 85.75 & 53.00 & 317.05 & 56.43 \\
\hline 25 & $\mathrm{Na} / \mathrm{k}$ & 0.91 & 0.61 & 1.13 & 0.06 & 0.07 & 0.08 & 1.92 \\
\hline
\end{tabular}

A - Ijebu Ife Pegmatite = Barren (2012); B - Apomu (2012) = Barren; C - Ago Iwoye (2011) = Barren; D - Komu = Mineralized; E - Cape de creus, Catalonia Spain = Mineralized; F - Emure Ekiti and G - Ijero Ekiti.

The weight percentage show that the whole rock samples $J_{1}-J_{3}$ is more siliceous with $66.6-71.00$ wt $\%$ then the muscovite samples $\mathrm{J}_{4}-\mathrm{J}_{5}$ with 43. $66-44.05 \mathrm{wt} \%$ and also contain lower alumina 12.60-14.40 wt \% compared with the muscovite samples 34.37-35.92 wt \%. This reflects the differences in the mineralogy of the samples. The high ratio of $\mathrm{Al}_{2} \mathrm{O}_{3} / \mathrm{Na}_{2} \mathrm{O}+\mathrm{K}_{2} \mathrm{O}+\mathrm{CaO}$ in the samples indicate peraluminous pegmatites with a probably plagioclase $\mathrm{Na}-\mathrm{Ca}$ feldspar mineralogy for the whole rock samples.

The result shows the comparison of the Emure and Ijero-Ekiti whole rock with the other highly siliceous and aluminous pegmatites in Nigeria and other parts of the world. The trace of Sn-Ta elements in Ijero-pegmatites; which were not detected in the Emure-Ekiti show that the Ijero pegmatites samples are more mineralized than the Emure pegmatites.

\section{DISCUSSION}

The analytical results presented in Table 1 show that the Emure pegmatites are highly siliceous; ranging from $65.68 \%-72.76 \%$ with an average value of $68.72 \%$. While on the other hand the Ijero pegmatites as seen in Table 2, ranges from $66.6 \%-71.00 \%$ for whole rock and $43.66 \%-44.05 \%$ for the muscovite samples. This high silica content in the Emure-Ekiti pegmatites are comparable with the "barren" Ijebu-Ife pegmatites. $\mathrm{Al}_{2} \mathrm{O}_{3}$ ranges from $18.99 \%-22.32 \%$ with an average value of $20.42 \%$ for Emure-Ekiti pegmatites and $12.6 \%-14.40 \%, 34.37-35.92 \%$ for the Ijero-Ekiti whole rock and muscovites respectively. Mean values for the major oxides are; $\mathrm{K}_{2} \mathrm{O}$ $3.17 \%, 6.09 \%$ for Emure and Ijero-Ekiti, respectively. Also, average values for $\mathrm{CaO} 0.02 \%, 1.15 \%$, $\mathrm{Fe}_{2} \mathrm{O}_{3} 1.83 \%, 1.16 \%, \mathrm{TiO}_{2} 0.17 \%, 0.086 \%, \mathrm{MgO}$ $0.013 \%, 0.58 \%, \mathrm{Na}_{2} \mathrm{O} 1.01 \%, 3.06 \%$ for Emure and Ijero-Ekiti pegmatites respectively. Statistical summary for trace and rare elements (Tables 1 and 2) shows some of the following averages values Ta 70 ppm, 40 ppm, Nb 87 ppm, 57 ppm, Sn $34 \mathrm{ppm}, 66 \mathrm{ppm}$ respectively for the Ijero-Ekiti pegmatites whole rocks and the muscovite samples respectively. While the averages for EmureEkiti pegmatites for both trace and rare elements are Ba 146 ppm, 90 ppm, Rb 482 ppm, 240 ppm, Y $53 \mathrm{ppm}, 120 \mathrm{ppm}, \mathrm{Zr} 50 \mathrm{ppm}, 60 \mathrm{ppm}$, Li 51 $\mathrm{ppm}, 106 \mathrm{ppm}$ respectively. The remaining trace elements and rare earth elements have relatively high values and are exclusive to the Emure-Ekiti pegmatites.

The results from Table 3 indicates the $\mathrm{SiO}_{2}$ (\%) of Ijebu Ife, Apomu and Ago-Iwoye, EmureEkiti and Ijero-Ekiti are approximately the same at $(65.9,69.3$ and 73.7$) \%$ respectively with Cape de creus with concentration of $\mathrm{SiO}_{2}$ been $46.65 \%$. The case is however different for $\mathrm{Al}_{2} \mathrm{O}_{3}$ concentration of the pegmatite. Cape de creus has the highest concentration of the metallic oxide at $36.8 \%$ while Ijebu has the least concentration at $13.7 \% \mathrm{Al}_{2} \mathrm{O}_{3}$. The Concentration $\mathrm{K}_{2} \mathrm{O}$ for Komu and Cape de creus concentrations at (10.3 and $9.5) \%$ respectively and only $1.86 \%$ concentration 
at Ifebu-Ife as the least concentration. For the trace and rare metals, Komu and Cape de creus have $\mathrm{Nb}$ has peak concentration of about $360 \mathrm{ppm}$ and $340 \mathrm{ppm}$ respectively. While the others is insignificantly low with concentration less than 50 ppm except for the Nb concentration at Ijero Ekiti which is $87.0 \mathrm{ppm}$. Komu has the high Ta Concentration at $77 \mathrm{ppm}$, closely followed by Ijero-Ekiti with $70 \mathrm{ppm}$ Ta concentration, with Ta being near $0 \mathrm{ppm}$ at the other locations.

Chemical characterisation of the Emure-Ekiti and Ijero-Ekiti Pegmatites from Tables 2, Ijero Ekiti (whole rock) indicates that $\mathrm{K} / \mathrm{Rb}$ ratio of the sample is very low (in the rare class zone) thereby indicating progressive fractionation and possible mineralization. The other samples of the whole rock from Ijero have values that are consistent with the barren zone while the muscovite extracts are mineralized [3].

The $\mathrm{Zr} / \mathrm{SiO}_{2}$ ratio (Table 3 ) is a geochemical variation used for determining or characterizing sample as magmatic or after magmatic. The values reveal that Emure-Ekiti Pegmatites are completely magmatic suggesting pegmatites to be genetically magmatic [7]. The Ijero-Ekiti sample also reveals magmatic field except the muscovite sample which have values that are consistent with the "AM" after magmatic field which connotes that the samples have been subjected in post magmatic alteration. The geochemical characterisations of the Pegmatites are determined using various geochemical variation ratios. The ratio, $\mathrm{K} / \mathrm{Rb} \mathrm{vs} \mathrm{Rb}$, $\mathrm{Zr}$ vs $\mathrm{SiO}_{2}$, and $\mathrm{K} / \mathrm{Rb}$ vs $\mathrm{Rb}$ were used as indices. This ratio is a geochemical variation for determining the degree of fractionation in pegmatite and then very useful tool for economic evaluation and chemical characterization of pegmatites for rare metals. In another study, they opined that extreme fractionation of lithophile elements such as $\mathrm{Rb}$ and $\mathrm{Cs}$ is a common geochemical feature of granitic pegmatites, especially the rare metal bearing types. Hence, late state progressive fractionation crystallization leads to decrease in $\mathrm{K}$ : $\mathrm{Rb}$ ratio, this suggesting metasomatism and invariably mineralization [11].

\section{CONCLUSION}

In the light of the analyses, results and interpretation given so far, this research work can be said to have achieved its aim and objectives: to carry out a comprehensive geochemical study of the Ekiti and Ijero-Ekiti Pegmatite and to compare the mineralogy and geochemistry of the pegmatites with those of the other parts of Nigeria and the world. The geochemical study carried out on these pegmatites revealed the Emure-Ekiti pegmatites belongs to the magmatics field and are "barren" - poorly fractionated and mineralized, as the rare metals indicative elements $\mathrm{Ta}, \mathrm{Nb}, \mathrm{Rb}$, $\mathrm{Cs}$ and Sn are either absent or very low in values. This Emure-Ekiti pegmatites also compare favourably with other barren pegmatites bodies in South-western Nigeria like the Apomu, AgoIwoye and Ijebu-Ife pegmatites and other part of the world. Studied from the Ijero-Ekiti pegmatites on the other hand, showed that two of the whole rock samples were plotted in the mineralized zone-highly differentiated, but the other whole rock sample and the muscovite samples plot in the "barren" zone, this may result as either low degree of fractionation of the samples. The depletion in $\mathrm{Sr}, \mathrm{Zr}$ and $\mathrm{Ba}$ coupled with fairly enrichment in $\mathrm{Nb}$, Ta in the Ijero-sample whole rock are comparably to some of the "rare metal" bearing pegmatites in the south western Nigeria e.g. Egbe, Komu and others from the Northern part of the country and the world. $\mathrm{Rb}, \mathrm{Sn}, \mathrm{Li}$ values of the Ijero pegmatites are fairly high but not up to the concentration level of most mineralized pegmatites.

Given the increase in demand for rare earth mineral globally, this research work serves as the quest for detecting and discovering more explored pegmatite bodies in Nigeria, its geochemical characterization and economical evaluation for its rare metal potentials.

\section{RECOMMENDATION}

From the result of the analysis, their seems to be high concentration values for some rare earth elements in the likes of $\mathrm{Ti}, \mathrm{Nd}$ and $\mathrm{Sm}$, with this, irrespective of whether the pegmatite is barren or mineralized, these rare earth elements can be of great economics potential as the advancement in technology highly demand these elements e.g. Sm - Nd as component of aerospace magnet and communication devices. A more thorough investigation is needed in the search and probably any exploration potentials of these rare earth elements in the area.

\section{References}

[1] R. Shaw and A. Gunn, "Petrogenesis of Rare-metal pegmatite in high grade metamorphic terranes: A case study from the Lewisian Gneiss Complex of north west Scotland," Precambrian Research, vol. 281, no. 24, pp. 338-362, 2016.

[2] R. Huckey and H. Jones, Geological survey of Nigeria, 1964.

[3] M. Matheis, G.and Caen-Vachette, "Rb- Sr isotopic study of rare metal bearing and barren pegmatites in the pan-African reactivation zone of Nigeria," J. Afri. Earth Sci., vol. 1, no. 1, pp. 35-40, 1983.

[4] W. Emofurieta and G. Matheis, "Petrology and geochemistry of the tin-bearing Pegmatites of Ijero-Ekiti and its environs, South-Western Nigeria," Borno Journal of Geology, vol. 2, no. 1, p. 18, 1978.

[5] G. Matheis, W. Emofurieta, and S. Ohiwerei, "Trace Element Distribution in Tin-bearing Pegmatites of Southwestern Nigeria," in Mineralization associated with acid Magmatism, A. Evans, Ed. New York: Willey \& Sons, 1987, pp. 205-220.

[6] G. Matheis, "Nigeria rare metal pegmatites and their lithological framework," in African Geology Reviews, P. Bowden and J. Kinnaird, Eds., vol. 22, 1987, pp. 271291.

[7] A. Ajibade and J. Wright, "Some metallogenetic feactures of Nigerian Basement," Journal of African Earth Sciences, vol. 6, no. 5, pp. 655-664, 1987.

[8] P. Ale, J. Dada, and A. Adewunmi, "Industrial minerals potentials of Ijero pegmatite in Ekiti State, Southwestern Nigeria," World Applied Science Journal, vol. 29, no. 3, pp. 415-420, 2014. 
[9] D. Kuster, "Rare metal pegmatite of wamba; central Nigeria, their formation in relationship to late PanAfrican granite," J. Mineral Deposita, vol. 25, no. 5, pp. 25-33, 1990.

[10] O. Okunlola and O. Ocan, "The expected environmental impact and mitigation studies of organized mining of rare metals ( $\mathrm{TaO}-\mathrm{Sn}-\mathrm{Nb}$ ) pegmaties around Keffi-area, North central," Nigeria. J. Env. Ext, vol. 3, no. 1, pp. 64-683, 2002.

[11] I. Garba, "Late Pan-African Tectoniccs and Origin $\mathrm{Au}$ mineralization and Rare metal Pegmatites in the Kushaka Schist Belt northwestern Nigeria," Journal min.Geology, vol. 38, no. 1, pp. 1-12, 2012.

[12] O. Okunlola and O. Ogedengbe, "Investment potentitals of gemstone occurrences in southwestern nigeria," in Prospects for investment in mineral resources of southwestern Nigeria, A. Elueze, Ed., 2003, pp. 41-45.

[13] O. Okunlola and P. King, "Process test work for the recovery of Tantalite. Columbire concentrates from rare metal pegmatites of Nasarawa area, central Nigeria," Global J. Geol. Sci, vol. 1, no. 1, pp. 85-103, 2003.

[14] O. Okunlola and E. Sornorin, "Compositional features of Precambrian pegmatites of Itakpe area, central Nigeria," NMGS conference abstracts, 2005

[15] O. Okunlola, "Metallogeny of Ta-Nb Mineralization of Precambrian pegmatites of Nigeria," Abstracts, 32nd IGC, Florence, Italy, 2004.

[16] A. Adetunji, "An assessment of the economic potentials of the pegmatite bodies of Komu area, Oyo State, southwestern Nigeria," Master's thesis, Obafemi Awolowo University, Ile-Ife, Nigeria, 2004

[17] A. Olugbenga, G. Okunlola, and B. Ofonime, "Petrochemical characteristics and age of rare metal (Ta$\mathrm{Nb}$ ). Mineralization in Precambrian Pegmatites, Komu, Nigeria," Int. J. Ecology and Environ. Geol., vol. 1, no. 7, pp. 21-26, 2011.

[18] A. Akintola, P. Ikhane, O. Okunlola, G. Akintola, and O. Oyebolu, "Compositional feactures of pre-Cambrian Pegmatites of Ago-iwoye area, SW Nigeria," Journal of Ecology and the Natural Environment, vol. 4, no. 4, p. 76, 2012.

[19] A. Akintola, P. Ikhane, O. Okunlola, G. Akinlola, and A. Adekoya, "Geochemical features of the Precambrian Pan-African pegmatites of Ijebu-Ife area, SW Nigeria," Environmental Ecology and Management Journal, vol. 1 , no. 3 , p. $41,2012$. 